\title{
Corruption in Indonesia (Is It Right to Governance, Leadership and It to Be Caused?)
}

\author{
Hendi Prihanto \\ Itjang D. Gunawan
}

\begin{abstract}
Purpose - The development of corruption in Indonesia which concerns various efforts and strategies are implemented but has not been able to maximize results. Poor governance, technology that is less able to use wisely and appropriately, and leadership that has not been able to set an example and figure are problems that need to be studied in depth as a cause of corruption that cannot be controlled. Pentagon Fraud is a theoretical approach chosen in solving research problems.

Design / Methodology - quantitative approach with causality relationship with multiple regression analysis techniques used, because the type of research that uses samples obtained with primary data has a frequency that is quite safe and varied, which includes several ministries and institutions which according to media observations commit corruption in 2017-2018 involving state aparters in the institution.

Findings - statistical data processing shows that governance and information technology has a positive effect on corruption, while leadership has a negative effect on corruption. The results showed the need for improvement in the management of government organizations, leadership more committed to duties and obligations, while the ease and use of information technology was carried out for positive purposes.

Research limitations / implications - research is only conducted on some state institutions involved in corruption in the research year by using the perceptions of the state apparatus who have information about corruption, so the results obtained are not able to conclude as a whole. Further in-depth research is needed by involving respondents and broader government organizations and a diversity of variables, to be able to infer aspects of the causes of corruption in general. Besides, the research provides a good enough use-value for the government to make improvements, resolve corruption problems both prevention and eradication precisely and strategically. The theoretical aspects of research contribute to several findings that can develop aspects of the causes of motivation to commit corruption so that it becomes a study that increasingly criticizes the harmony and balance between theory and practice.
\end{abstract}

Keywords: corruption, governance, leadership, information technology, and government

DOI: $10.7176 / \mathrm{JESD} / 11-2-06$

Publication date: January $31^{\text {st }} 2020$

\section{INTRODUCTION}

Corruption is part of a crime of fraud with the motive of expropriation, robbery, theft or embezzlement carried out clandestinely or openly for personal gain that harms others. This opinion was expressed by the Association of Certified Fraud Examiners (ACFE) (2016) and classifies the Fraud in the Fraud Tree which is divided into three major types, namely: Corruption, Asset Misappropriation, and Fraudulent Statements (Financial Statement Fraud). ICW (Indonesian Corruption Watch) data in 2016 stated that Rp. 3 trillion in total state losses caused by corruption. Then the ICW Judicial and Legal Monitoring Division stated that there were around Rp. 3.085 trillion in the value of state losses due to corruption cases in Indonesia (source: national.tempo.co; March 4, 2017). Thus corruption is a very detrimental crime and endangers the survival of the country. The handling of corruption by anti-corruption state institutions and internal efforts in preventing state losses do not seem to produce satisfactory results because the amount has not been reduced. Crowe Horwarth (2011) argues that corruption can be caused by several things such as competence, arrogance (pressure), opportunity (opportunity), and rationalization (rationalization) which later became known as the Pentagon Fraud.

Hopper (2017) argues that the culture of neopatrimonialism impedes the optimal development of good governance. Good governance is one way to reduce fraud as stated by Arens, Elder and Beasly (2011) that management is responsible for implementing governance, as well as control procedures that minimize the risk of fraud through a combination of preventive, anticipatory and detection actions. By implementing anti-fraud programs and controls, management can prevent fraud by reducing opportunities that allow fraud to occur. The aspect of advancement in technology depends on the advancement of knowledge, nowadays technology through empirical and experimental research develops itself and the implication is that at a certain point there is a conflict between the value of knowledge and the value of using that technology, IT carries a greater influence on organizational performance. technology and governance are inseparable unity, research conducted by Sharma \& Panigrahi (2012), Chen et al. (2014), and Halbouni \& Garbau (2016) stated that governance, fraud, and technology have a close relationship, implementation in several developed and developing countries have different levels of success. 
Prabowo \& Cooper (2017) states that corruption in the Indonesian public sector is the result of a cumulative decision-making process by the principals who are mostly leaders, for this reason, corruption prevention is directed at eliminating knowledge about corruption, both in tacit and explicit forms and replace it with knowledge of good governance, accountability, and integrity. Good leadership and governance in the delivery of government affairs are needed with the support of adequate information technology. The concept of good governance (GG) makes it easy for the government to carry out large operations properly and directed. Leadership is related to moral standards, influencing the good and bad behavior of an organizational leader as measured by the statement of its members because leadership is also related to employee morale (Lee et.al., 2017; Mo \& Shi, 2017). The aspect of the application of ethical leadership by Gerpott et al., (2017) shows that reciprocity of subordinates to engage in work behavior provides benefits in improving morale because leaders who behave ethically show impartiality, fairness, and trust in behavior. Cases of corruption in the procurement of e-KTPs in Indonesia (source: detikNews.com. 17-07-07) are problems involving leaders in Indonesia, even though they have higher education and the financial and economic conditions are sufficient, they continue to carry out corruption as revealed by Tuannakota (2007).

Efforts made by the government with a lot of corruption that is currently making several strategies by making a ban on indications of actions including corruption, sanctions and vigorous socialization of anti-corruption to increase the revenue of the authorities by providing benefits to them. This research is motivated by interesting and motivating researchers to better examine how effective prevention efforts are carried out and the results obtained to prevent corruption by knowing the main problems outlined in the research variables. Through some identification of the causes of corruption, the research aims to examine and explain the effects of government governance, leadership and the use of information technology that contribute to the causes of corruption in Indonesia. Research is beneficial for academics in developing scholarship on the problem of the causes of corruption which have not been obtained with certainty the motivation of the perpetrators so that with a practical approach to the government will be obtained accuracy between the theory and reality that occurs. Thus it can take the formulation of strategies and policies in managing and preventing corruption problems so that they do not progress and create anti-corruption government organizations.

\section{LITERATUR REVIEW}

\section{Government Function}

The government should be a state organizer capable and functioning to prosper and prosper the people and anticorruption (Ndraha, 2007), so if the government actually carries out corruption and is not trustful of the mandate given by its people to it, thus it can be assured that there will be agency conflicts like those put forward by Jensen and Meckling (1976) in Agency theory. Agency conflicts often arise in the government when the government as an agent is unable to act as the people want and want (principals). The behavior of the government that is not honest and trustworthy because of the asymmetry of information with the people, because the government's behavior is embezzlement, theft, deviation, lying, and abuse the authority to manage the state entrusted by the people to him for personal or group interests.

\section{Factors that cause corruption}

Corruption in RI Law No. 31 of 1999 concerning eradicating criminal acts of corruption states that "every person who is categorized as against the law, commits acts of enriching oneself, benefits oneself or another person or a corporation, abuses his authority or opportunity or means because of positions or positions that can harm the country's finances or the country's economy. " The Pentra Fraud Theory (Crowe's fraud pentagon theory) proposed by Crowe Horwarth (2011) states that competence, opportunity, pressure, rationalization, and arrogance are the causes of someone committing corruption (fraud) as the model in Figure 2.1. Competence or capability is the ability of employees to ignore internal controls, develop concealment strategies, and control social situations for personal gain. While arrogance is an attitude of superiority over the rights held and feels that internal control or company policy does not apply to him, these two dimensions of the causes of corruption that distinguishes from the theory of fraud previously proposed.

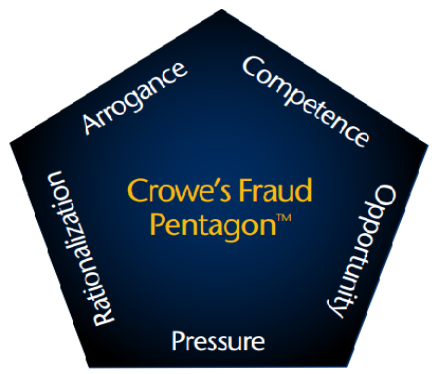

Figure 2.1 Pentagon Fraud 


\section{Good governance}

Good governance is the implementation of solid and responsible development management that is in line with the principles of democracy and an efficient market, avoiding misallocation of investment funds and preventing corruption both politically and administratively carrying out budgetary discipline and creating a legal and political framework for growth. business activities. Good governance according to UNDP (LAN, BPKP 2000) must meet elements such as Participation, Legal Certainty, Responsibility, Consensus, Fairness, Effectiveness \& Efficiency, and Vision and Mission.

\section{Leadership}

Colquitt, LePine, and Wesson (2015) state that leadership is the use of power and influence to direct followers to achieve goals through directing efforts that can influence followers' interpretation of events, the organization of their work activities, their commitment to the main objectives, relationships with other followers, access to cooperation and support from other work units. Leadership will be effective if it meets the criteria set in the opinion of Ivancevich, Konopaske and Matteson (2008) which can be shown by the nature of the leader in the following dimension criteria: intelligence, personality and abilities/intelligence.

\section{Information Technology}

Information technology that is considered very influential and is often used to explain individual acceptance of the use of technology systems is the Technology Acceptance Model (TAM), a model to predict and explain how technology users accept and use technology related to the work of users of belief (belief), attitudes ( attitude), intention (intention) and the relationship of user behavior (user behavior relationship). Davis (1989) states that TAM is a model used to predict user acceptance of technology based on two variables, namely perceived usefulness and perceived ease of use. The main purpose of TAM is to establish a basis for tracing the influence of external factors on the attitude (personalization) and goals of computer users.

\section{HYPOTHESIS DEVELOPMENT}

\section{Governance against corruption}

Governance is defined as a tool and mechanism used in managing an organization that has a large and significant impact on the performance of an organization, Hopper (2017) states that neopatrimonialism (corruption, collusion, and nepotism) can inhibit the development of governance optimally. Blackburn \& Forgues-Puccio (2009); Aidt et.al .; and Wilson (2008); Jalilian et.al., (2006); Pellegrini \& Gerlagh, (2004); and Mauro (1995) stated that bad governance and corruption were caused by the government having bad governance and law enforcement in the country. Whereas Tseng \& Su (2013); Yusuf \& Babalola (2009); Crocker \& Tennyson; Derrig; and Dionne \& Gagne (2002) state that fraud occurs due to market failures, asymmetry of information and bad regulations that lead to opportunities for fraud. Then Agyei \& Mensah (2017); Caiden (2013); Rose-Ackerman et.al. (2012); and Law (2011) states that corporate governance is positively related to low corruption, especially in good governance (Habibullah et.al. 2016). Thus the better the bad organizational governance will become the cause of corruption, the research hypothesis one $(\mathrm{H} 1)$ can be stated :

\section{H1: Poor governance has a positive effect on the causes of corruption}

\section{Leadership against corruption}

Leadership is needed to achieve the organization's vision and mission and make it better, bad leadership will bring the organization to ruin. Several leadership studies such as Simpson (2013) state that the perpetrators of elite leaders' crimes on corruption are motivated by greed, which is why according to Braga \& Clarke (2014); Fagan (2013); Braithwaite (2012); and Clarke \& Felson (2010) assert that crime prevention begins with increasing the social capital of a leader and its members. Another case with Lenard et.al (2017) states that organizations led by women are better able to reduce corruption so that it effectively makes the organization not corrupt and performs well (Prabowo et.al 2017). Sharma (2009) states that organizational success is due to a strong leadership balance and can prevent corruption (Graycar 2018). Then Masters \& Graycar (2016); Graycar (2015); and McAllister et al. (2012) stated that corruption in rich countries is lower than poor countries. Furthermore, Wertz et al. (2016); Ibraheem; \& Bendahan et al. (2015); Lammers \& Van Beest (2014); Malhotra \& Gino; \& Inesi et al. (2012) states that power is a factor in the occurrence of corruption because the abuse of power is carried out by leaders for corrupt purposes of power (Ibraheem 2015) because for leaders the temptation of corruption is the most difficult to avoid (Lammers \& Van Beest, 2014). Thus a leader who is not good and qualified can cause corruption so that the research hypothesis two $(\mathrm{H} 2)$ can be stated that:

H2: poor leadership has a positive effect on the causes of corruption

\section{Information technology against corruption}

Technology is a means for humans to help work and do activities, therefore technology has an important role in 
supporting work success. Halbouni \& Garbau Research (2016); and Ott (2010) state that the wrong use of technology can create fraud, so the utilization of information technology is divided into two more categories namely usefulness and effectiveness (Chin \& Todd, 1995). Chen et al. (2014); Sharma and Panigrahi (2012); Zhou \& Kapoor; and Ngai et al. (2011); Krambia-Kapardis (2010); Grove \& Basilico; and Janvrin et al., (2008); and Bierstaker et al .; and McKee (2006) state that there is a strong relationship between corruption and technology, but its application in developed and developing countries is not all appropriate and successful. It was further stated that using IT was able to prevent, monitor and control corruption (Tang 2018; Halbouni and Garbau; Akomea 2016; Quah; and Xin Li 2015; Bussell 2010; Shim \& Eom 2009; and Bhatnagar 2003). The use of poor technology will lead to corruption so that the three research hypotheses $(\mathrm{H} 3)$ can be put forward as follows:

H3: Incorrect technology in utilizing positively influences corruption.

The thinking framework can be illustrated in Figure 2.1 which illustrates the overall hypothesis that positively influences the independent variable on corruption.

Figure 2.1

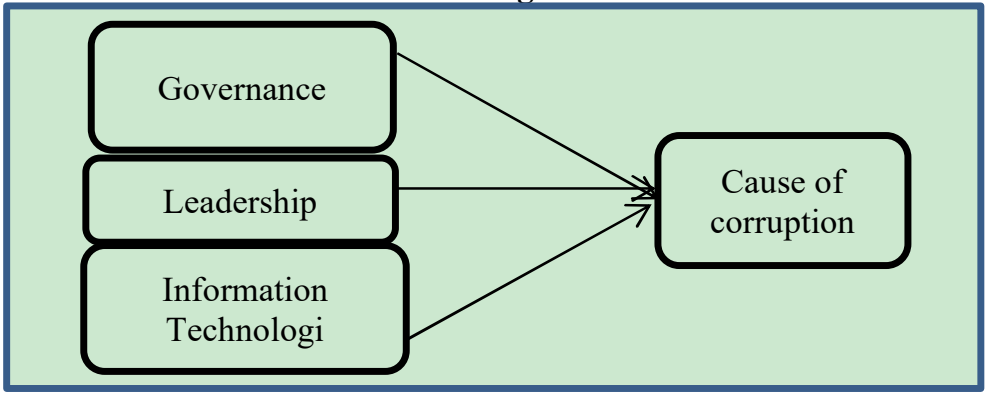

\section{RESEARCH METHODS}

\section{Research design}

Design in research uses a type of quantitative research causal relationship that explains the effect between two independent and dependent variables. The research sample was obtained by using a purposive sampling technique which is a way to determine specific characteristics that are suitable with the research objectives so that it is expected to answer the research problem. The research object uses several ministries and high state institutions that have experienced corruption in 2017-2018 such as Ministry of Religion, Health, Transportation, PUPR, BPK RI, Ministry of PDTT, Ministry of Home Affairs, Ministry of Youth and Sports, Ministry of Youth and Sports, BKKBN, and Ministry of Finance. Completion of the research questionnaire obtained as many as 100 pieces obtained through Google forms, disseminating directly or in the event of a coordination meeting conducted at the Ministry of Finance. Research subjects are auditors or echelon 3 and 4 officials (section heads, subsection heads, and section heads) as parties who understand the problem of corruption in their respective organizations and understand the filling of the research questionnaire.

\section{Measurement of variables}

Corruption is measured using the Pentagon theory of fraud approach proposed by Crowe Howart (2011), namely: arrogance, competence, opportunity, pressure, and rationalization. Governance is then measured according to UNDP (LAN-BPKP 2000), namely: Participation, Legal Certainty, Responsibility, Consensus, Fairness, Effectiveness and Efficiency, and Vision and Mission. Leadership variables are measured according to Ivancevich, Konopaske, and Matteson (2008), namely: intelligence, personality, and abilities. Information technology is measured by perceived usefulness and perceived ease of use according to Davis (1989).

\section{ANALYSIS AND FINDINGS}

The reliability test results of each variable indicate that the Cronbach's alpha value of the value of government governance variables (X1) with a value of 0.918 , effective leadership (X2) with a value of 0.897 , information technology (X3) with a value of 0.871 and the cause of corruption (Y) with a value 0.862 thus the average value above 0.70 with a reference used from Cronbach's alpha is a minimum of 0.60 , based on the assumptions put forward by Nunnaly (1978). The results of the validity test showed that the value of each question numbered 54 pieces concluded that no value was less than or below 0.11 ( $\mathrm{r}$ table) which became the stipulation with the number of respondents as many as 100 people. Thus it can be concluded that the reliability and validity test of the data is following the role of thumb with a model that is suitable for use as a prediction with the results of the normality test of several research data not moving away from the regression line.

\section{Multiple Linear Regression Analysis}

Multiple linear regression analysis is used to determine the effect of two or more independent variables with one 
dependent variable, whether each independent variable is positively or negatively related to the dependent variable. The linear regression equation model used from the test results (see table 4.1) is as follows:

$$
\text { Corr }=30,158(\alpha)+0,126(\text { Gov) }-0,155(\text { Lead })+0,405(\text { IT })+6.139 \text { (error) }
$$

Note : $\alpha=$ intersep atau konstanta, Cov $=$ Goverenance, Lead=Leadership dan IT $=$ Teknologi information

Table 4.1

Regression and Hypothesis Testing

\begin{tabular}{|c|c|c|c|c|c|}
\hline \multicolumn{2}{|l|}{ Variabel } & Koefisien Regresi & $t$-test & p-value & Keterangan \\
\hline \multicolumn{2}{|l|}{ Korupsi } & - & 0.493 & - & - \\
\hline \multicolumn{2}{|l|}{ Governance } & 0.126 & 0.632 & 0.264 & positive not significant \\
\hline \multicolumn{2}{|l|}{ Leadership } & -0.155 & -0.796 & 0.214 & negative not significant \\
\hline \multicolumn{2}{|c|}{ Informasi Teknologi } & 0.405 & 1.514 & $0.066^{*}$ & positive significant \\
\hline Constanta & $: 30.158$ & - & - & - & - \\
\hline Error & $: 6.139$ & - & - & - & - \\
\hline Adjusted $\mathrm{R}^{2}$ & $: 0.051$ & - & - & - & - \\
\hline F test & $: 2.670$ & - & - & 0.052 & - \\
\hline
\end{tabular}

Note : guidelines for determining the level of significance of hypotheses $*=0.10, * *=0.05 . * * *=0.01, * * * *$ $=\mathbf{0 . 0 0}$

With a sample of 100 respondents obtained a constant value of 30.158 shows that corruption is equal to a constant, even though the independent variable has a zero value. Governance regression coefficient value of 0.126 means that it has a positive effect on the causes of corruption every 1 unit increase will affect the occurrence of corruption in Indonesia by $12.6 \%$. The leadership regression coefficient value of -0.155 means it has a negative influence, an increase of 1 unit will affect the cause of corruption by $-15.5 \%$. Information Technology regression coefficient of 0.405 means that it affects positively the cause of corruption, each increase in the value of 1 unit of the variable will affect the occurrence of corruption by $40.5 \%$

The results of statistical testing through the t-test using SPSS media obtained the results that Good Governance has at the count of 0.632 , a significance value of 0.264 or greater than 0.05 (alpha $\alpha=5 \%$ ) which has a positive effect, but is not significant so hypothesis one (H1) fails to be accepted. Leadership has at -0.796 with a significance value of 0.214 or greater than 0.05 (alpha $\alpha=5 \%$ ) which has a negative and insignificant effect, so hypothesis two (H2) also fails to be accepted. Information Technology has at count of 1,514 with a significance value of 0.06 greater than 0.05 (alpha $\alpha=5 \%$ ) but smaller than 0.10 and has a positive effect, so hypothesis three (H3) is accepted.

The coefficient of determination (R2) test results obtained an adjusted R square value of 0.051 , which means $0.51 \%$ of the independent variables can explain the model of the dependent variable, while the rest of $99.949 \%$ can be explained by other variables not done in the study. The results of testing the model using the F test showed that the $F$ value of 2,670 with a significance level of 0.052 or close to the level of $5 \%$, which means the model is rated in a category that is fit to be used to predict.

\section{DISCUSSION}

\section{The effect of Good Governance on the causes of corruption}

Government governance has a positive effect on corruption, although not significantly, the results of this study are in line with the research put forward by Blackburn \& Forgues-Puccio (2009); Aidt et.al .; and Wilson (2008); Jalilian et.al., (2006); Pellegrini \& Gerlagh, (2004); and Mauro (1995) that a government with poor law enforcement causes corruption. While the results of the study are not in line with Agyei \& Mensah (2017); Habibullah et.al. 2016; Caiden (2013); Rose-Ackerman et.al. (2012); and Law (2011) that good corporate governance causes low corruption. The results showed that the application of governance in Indonesia, especially to several ministries and state institutions that were proven to have committed corruption was not yet optimal, this proves that the behavior of corruption in a number of these institutions has not been prevented and minimized because there is still governance that has not been properly implemented. Corruption, collusion, and nepotism are big problems in Indonesia because it is very difficult to be eliminated or prevented because they are included in deeds done covertly. In line with the opinion of Hopper's research (2017) that Neopatrimonialism (corruption, collusion, and nepotism) can hamper the development of government governance to become good governance in the implementation of government organizations, thus creating problems in the nation and state development such as irregularities in the use of state money.

Poor or bad governance such as non-transparency, improper law enforcement, consensus will facilitate and 
create opportunities for corruption in the body of government organizations. Corruption is mostly carried out by officials who are supposed to be responsible when given mandate due to unclear and firm laws. Therefore serious reforms are needed in improving governance towards good governance for the country or organization to be good and achieve the vision and mission. For this reason, corruption prevention is directed to eliminate knowledge about corruption, both secretly and explicitly, and replace it with knowledge of good governance, accountability, and integrity (Prabowo, et.al., 2017). Conflicts of interest, unhealthy politics, laws that are not committed to implementing improvements in the country, cause corruption to have opportunities to grow, state governance or government performance can be of high quality depend on the governance of the government itself (Ndraha, 2007). Good governance is a mechanism for implementing solid and responsible development management that is in line with the principles of democracy and efficient market creation, lack of collusion and nepotism, and avoidance of misallocation of investment funds (development) and prevention of corruption carried out both politically and administratively in compliance in carrying out budget discipline, as well as the creation of a legal and political framework for the growth of government service activities for the better.

\section{The influence of leadership on the occurrence of corruption.}

The results showed that leadership harms corruption, meaning that although not significant, the role of leadership is not yet maximal in preventing and suppressing the rate of corruption. This is because most of the facts about corruption are carried out by leaders who have power, good economic conditions, are well educated and have opportunities (Tuannakota, 2007) and are in line with research conducted by Braga \& Clarke (2014); Simpson; Fagan (2013); Braithwaite (2012); and Clarke \& Felson (2010). Poor leadership is one of the dominant causes of corruption in the Indonesian government. This fact is not in line with the opinion of Ndraha (2007) that in fact, the government aims to lead a maximum life together without harming others illegally, therefore the government must be anti-corruption. Indonesia as a developing country is inseparable from the problem of corruption and becomes a dangerous disease (Masters \& Graycar, 2016; Graycar, 2015; and McAllister et al., 2012) therefore strong leadership is needed to prevent corruption (Graycar 2018 and Sharma, 2009), so that it is effective and the organization is performing well (Prabowo et.al 2017). Besides, the problem of leaders in Indonesia is that on average many leaders in Indonesia are not supported by their environment (people around like other leaders, colleagues or subordinates) so that they cannot bring maximum change (Bisnis.com, June 8, 2018) so that support for leaders need to bring about change for the better. This was also expressed by Ivancevich, Konopaske, and Matteson (2008) that leaders have abilities that can work together or ask other parties to collaborate with them through their diplomacy abilities.

Corruption behavior that has so far been carried out by officials, as well as organizational behavior (organizational behavior and institutional behavior) that functions as the organizer of power (government/leader / governing) and almost does not lie in the analysis of the state as a system of power itself (Ndraha, 2007) meaning that there is no conformity with the relationship. This fact of leader corruption is in line with Agency theory put forward by Jensen and Meckling (1976) that the government as an agent is not trustful of the obligations imposed and provided by principals by violating information or asymmetry (reporting false or fictitious) and also misusing assets and wealth that should be used for the welfare and prosperity of the people (principals). For example, deviations made by the government or leaders are projects or work that is not done as it should, such as misuse of the budget and theft of state money for personal gain (for example e KTP cases). Power becomes the cause and tool for abuse of authority by leaders (Wertz et al. 2016; Ibraheem; and Bendahan et al. 2015); Lammers \& Van Beest (2014); Malhotra \& Gino; and Ines et al., 2012) for this reason, it is necessary to limit and supervise to avoid abuse of power by leaders, as stated by Crowe Howarth (2011) that opportunity is a strong factor capable of causing corruption. With the ability and arrogance supported, the power of the leader can become arrogant and then rationalize his actions which are not true.

\section{The influence of information technology on the causes of corruption}

The results showed that the use of information technology had a positive effect even though the lowest significant level was 0.10 . Information technology is a tool that can be used as a tool for corruption but can also be used as a tool to prevent and control corruption. The results of the study are in line with the results of the research proposed by Halbouni and Garbau (2016) and Ott (2010) that the use of the wrong technology can create fraud so that it can be said that the use of technology is still not maximized so that it fails or is less able to prevent and control corruption. To be able to conclude that there is a strong relationship between the occurrence of corruption and the use of information technology, Indonesia is included in the category of developing countries that have not been maximized in utilizing information technology properly so that it is different from developed countries that can implement and maximize the use of information technology (Chen et al., 2014 Sharma \& Panigrahi 2012; Zhou \& Kapoor, 2011; Ngai et al., 2011; Krambia-Kapardis, 2010; Grove \& Basilico; and Janvrin et al., 2008; and Bierstaker et al .; and McKee, 2006).

Information technology is very important in advancing the organization because IT can be obtained speed in 
working, speed and accuracy in obtaining information as well as accuracy and speed in decision making. For that reason, in its application IT is a concern of the government because IT is not infrequently IT sophistication tends to be used by parties who are not responsible as criminals, to commit crimes (cybercrime) by taking assets and others without being known and realized. This is because IT with a virtual system is very possible to commit crimes unnoticed such as hackers who manipulate data, spread viruses, and steal organizational data. In line with the results of Ott's research (2010) that information technology is used for corruption by bank employees, lawyers, accountants, and security, or other people who intend not to engage in money laundering or theft activities, financial fraud by utilizing and carrying out high-tech computer disturbances. Therefore, the technology currently used should have or be equipped with strong security, because if it is used under certain conditions and with bad impetus by utilizing certain parties (Davis, 1989), then this will produce a conspiracy of users who have the motivation not good will be very detrimental to the organization. By preventing through inherent supervision of the use and use of information technology, corruption can be minimized and prevented (Tang 2018; Halbouni \& Garbau; Akomea 2016; Quah; and Xin Li 2015; Bussell 2010; Shim \& Eom 2009; and Bhatnagar 2003).

\section{CONCLUSIONS AND LIMITATIONS}

The results of the study concluded that government governance and leadership in several organizations (subjects in the study) have a tendency not to be maximized to be implemented and applied so that corruption is still very potent and has a great opportunity to occur in several government organizations and is carried out by organizational leaders. While the implementation of the use and ease of information technology has not been maximally applied and may be more likely to be used for matters and engineering that facilitate acts of corruption, so IT does not support organizational performance to better realize the organization's vision and mission.

With the results obtained, especially in several hypothesis tests that are less than the maximum makes several weaknesses and deficiencies in research, these limitations are less able to conclude the results with a limited number of samples only in several specific government organizations that are the focus of research with less good results (goodness) of fit). The low coefficient of determination test results shows that the independent variable is less able (weak) to be a variation of the model to predict the cause of corruption. To develop this research better, it is recommended to use other variables that can be more powerful to predict or combine, of course by adding several research samples and observation areas so that they are better able to conclude the results as a whole or the majority. Then the results of the study were also able to attract attention and reference to several government organizations that are used for government policymaking, or management of other organizations in managing effective organizational governance oriented leadership to avoid corruption crimes through the use of information technology. For academics, this research is a reference for developing similar research that will complement scientific scholarship in the future, and improve solutions to prevent and eradicate and minimize corruption by building relevant theories.

\section{REFERENCES}

ACFE. (2016). Report to The Nation on Occupational Fraud and Abuse. Austin, Texas: Association of Certified Fraud Examiners.

Agyei, B. Kwame-Mensah, (2017) "The relationship between corporate governance, corruption and forwardlooking information disclosure: a comparative study", Corporate Governance: The International Journal of Business in Society, Vol. 17 Issue: 2, pp.284-304, https://doi.org/10.1108/CG-11-2015-0150

Aidt, T., Dutta, J., \& Sena, V. (2008). Governance regimes, corruption and growth: Theory and evidence. Journal of Comparative Economics, 36(2), 195-220. doi:10.1016/j.jce.2007.11.004

Akomea, Isaac-Frimpong, Andoh, Charles, Eric Dei Ofosu-Hene, (2016), Causes, effects and deterrence of insurance fraud: evidence from Ghana, Journal of Financial Crime, Vol. 23 Issue: 4, pp.678-699, https://doi.org/10.1108/JFC-11-2015-0062

Arafat, Wilson (2008). How to implement GCG (good corporate governance) effectively: mengungkap horison 8 langkah membumikan sistem dan budaya GCG, Skyrocketing Pub.

Arens, Arvin A, Randal J. Elder and Mark S. Beasley. (2008). Auditing dan Jasa Assurance Pendekatan Terintegrasi.Jilid1: Edisi Keduabelas. Jakarta: Erlangga.

Bendahan, S., Zehnder, C., Pralong, F. P., \& Antonakis, J. (2015). Leader corruption depends on power and testosterone. The Leadership Quarterly, 26(2), 101-122. doi:10.1016/j.leaqua.2014.07.010

Bhatnagar, S., (2003). E-government and access to information. Global Corruption Report 2003. Washington DC: Transparency International.

Bierstaker, J.L., Brody, R.D., Pacini, C., (2006). Accountants' perceptions regarding fraud detection and prevention methods. Managerial Auditing Journal, 21(5), 520-535

Blackburn, K., \& Forgues-Puccio, G. F. (2009). Why is corruption less harmful in some countries than in others? Journal of Economic Behavior \& Organization, 72(3), 797-810. doi:10.1016/j.jebo.2009.08.009

Braga, A. A., \& Clarke, R. V. (2014). Explaining High-Risk Concentrations of Crime in the City. Journal of 
Research in Crime and Delinquency, 51(4), 480-498. doi:10.1177/0022427814521217

Braithwaite, J. P. (2012). Standard Form Contracts as Transnational Law: Evidence from the Derivatives Markets. The Modern Law Review, 75(5), 779-805. doi:10.1111/j.1468-2230.2012.00924.x

Bussell, Jennifer., (2010). Comparative Political Studies 2010 43: 1230 originally published online 11 May L. Reform in the Indian States W DOI: 10.1177/0010414010369073

Caiden, G. (2013). Public Administration in Asia. Public Administration Review, 73(3), 540546. doi:10.1111/puar.12033

Chen, Y., Smith, A.L., Cao, J. and Xia, W. (2014), "Information technology capability, internal control effectiveness, and audit fees and delays", Journal of Information Systems, Vol. 28 No. 2, pp. 149-180

Chen, Y., Wang, Y., Nevo, S., Jin, J., Wang, L., \& Chow, W. S. (2014). IT capability and organizational performance: the roles of business process agility and environmental factors. European Journal of Information Systems, 23(3), 326-342. doi:10.1057/ejis.2013.4

Chin, Wynne W. and Todd, Peter A.(1995). On the Use, Usefulness, and Ease of Use of Structural Equation Modeling in MIS Research: A Note of Caution., Management Information Systems Research Center, University of Minnesota. MIS Quarterly, Vol. 19, No. 2 (Jun., 1995), pp. 237-246

Clarke, R. V. \& Felson, M. (2010). The Origins Of The Routine Activity Approach And Situational Crime Prevention. In: F. Cullen, C. J., A. Myer And F. Adler (Ed.) The Origins Of American Criminology. New Brunswick: Transaction Press.

Colquitt, Jason A., Lepine, Jeffrey A, and Michael J. Wesson (2015). Organizational Behavior: Improving Performance and Commitment in The Workplace. Fourth Edition. McGraw-Hill Education, New York.

Crocker, K. J., \& Tennyson, S. (2002). Insurance Fraud and Optimal Claims Settlement Strategies. The Journal of Law and Economics, 45(2), 469-507. doi:10.1086/340394

Davis, F.D, R.P. Bagozzi, dan PR. Warshaw, (1989).User Acceptance of Computer Technology: A Comparison of Two Theoretical Models”, Management Science, 35 (8), pp. 982-1003,

Derrig, R. A. (2002). Insurance Fraud. Journal of Risk \& Insurance, 69(3), 271-287. doi:10.1111/15396975.00026

Dionne, Georges \& Gagne, Robert, (2002). Replacement Cost Endorsement and Opportunistic Fraud in Automobile Insurance," Journal of Risk and Uncertainty, Springer, vol. 24(3), pages 213-230, May

Gerpotta, Fabiola H., Lehmann-Willenbrockb, Nale, Silvisc, Jeroen D., Mark Van Vugtc (2017), In the eye of the beholder? An eye-tracking experiment on emergent leadership in team interactions, The Leadership Quarterly, http://dx.doi.org/10.1016/j.leaqua.2017.11.003

Graycar, A. (2015). Corruption : Classification and analysis; Policy and Society 34(2) - May 2015, DOI: 10.1016/j.polsoc.2015.04.001

Grove, Hugh and Elisabetta Basilico. (2008). Fraudulent Financial Reporting Detection Key Ratios Plus Corporate Governance Factors, Journal of Accounting Research, Vol. 38 No. 3, pp.10-42.

Habibullah, Muzafar Shah., Din, Badariah H., M. Yusof-Saari, A. H. Baharom (2016). Shadow Economy and Financial Sector Development in Malaysia, International Journal of Economics and Financial

Halbouni, Sawsan Saadi., Obeid, Nada., Garbou, Abeer. (2016). Corporate governance and information technology in fraud prevention and detection: Evidence from the UAE, Managerial Auditing Journal, Vol. 31 Issue: 6/7, pp.589-628, https://doi.org/10.1108/MAJ-02-2015-1163

Hopper, Trevor.(2017). Neopatrimonialism, Good Governance, Corruption and Accounting in Africa: Idealism versus Pragmatism, Journal of Accounting in Emerging Economies 7(2) · May 2017, DOI: 10.1108/JAEE12-2015-0086

Horwarth, Crowe. (2011). The Mind Behind The Fraudsters Crime: Key Behavioral and Environmental Element. USA: Crowe Horwarth International.

Ibraheem, T. O. (2015). Curbing abuses of legal power in the society. World Academy of Science, Engineering and Technology, International Journal of Social, Behavioral, Educational, Economic, Business and Industrial Engineering, 9(11), 3605-3608.

Inesi, M. E., Gruenfeld, D. H., \& Galinsky, A. D. (2012). How power corrupts relationships: Cynical attributions for others' generous acts. Journal of Experimental Social Psychology, 48(4), 795-803.

Ivancevich, John M.,Robert, Konopaske, and Michael T. Matteson, Organizational Behavior and Management, Boston: McGraw-Hill Companies, Inc.,2008

Janvrin, D., Bierstaker, J., \& Lowe, D. J. (2008). An Examination of Audit Information Technology Use and Perceived Importance. Accounting Horizons, 22(1), 1-21. doi:10.2308/acch.2008.22.1.1

Jalilian, H., Kirkpatrick, C., \& Parker, D. (2006). The impact of regulation on economic growth in developing countries: a cross-country analysis, World Development, 35, 87-103

Jensen \& Meckling, 1976, The Theory of The Firm: Manajerial Behaviour, Agency Cost, and Ownership Structure, Journal of Financial and Economics, 3:305-360

Krambia-Kapardis, M , Clark C. and Zopiatis A. (2016) Satisfaction Gap in Public Sector Financial Reporting, 
International Journal of Accounting in Emerging Economies, to be published vol 6 (3): 232-253.

LAN-BPKP, 2000. Akuntabilitas dan Good Governance. Jakarta: LAN-RI

Lammers, J., \& Van Beest, I., (2014). The effects of feeling of power on immorality. In J van Prooijen \& P.A.M van Lange (Eds.), Power, politics and paranoia: Why people are suspicious about their leaders (pp. 17-32). Cambridge University Press.

Law, Philip (2011) "Corporate governance and no fraud occurrence in organizations: Hong Kong evidence", Managerial Auditing Journal, Vol. 26 Issue: 6, pp.501-518, https://doi.org/10.1108/02686901111142558

Lee, D., Choi, Y., Youn, S. and Chun, J.U. (2017), "Ethical leadership and employee moral voice: the mediating role of moral efficacy and the moderating role of leader-follower value congruence", Journal of Business Ethics, Vol. 141 No. 1, pp. 47-57

Lenard, Mary Jane, Bing Yu, E. Anne York, Shengxiong Wu, (2017) "Female business leaders and the incidence of fraud litigation", Managerial Finance, Vol. 43 Issue: 1, pp.59-75, https://doi.org/10.1108/ MF-04-20160123

Masters, A. B., \& Graycar, A. (2015). Making Corruption Disappear in Local Government. Public Integrity, 18(1), 42-58. doi:10.1080/10999922.2015.1093400

Mauro, Paolo. (1995). Corruption and Growth, The Quarterly Journal of Economics, Vol. 110, No. 3 (Aug., 1995), pp. $681-712$

Malhotra, D., \& Gino, F. (2012). The pursuit of power corrupts: How investing in outside options motivate opportunism in relationships. Administrative Science Quarterly, 56 (4), 559-592.

McAllister, I., Pietsch, J., \& Graycar, A. (2012). ANU poll: Perceptions of corruption and ethical conduct Retrieved from http://politicsir.cass.anu. edu.au/polls-and-surveys/anupoll.

McKee, T.E. (2006), “Increase your fraud auditing effectiveness by being unpredictable!”, Managerial Auditing Journal, Vol. 21 No. 2, pp. 224-231.

Mo, S. and Shi, J. (2017), "Linking ethical leadership to employees' organizational citizenship behavior: testing the multilevel mediation role of organizational concern", Journal of Business Ethics, Vol. 141 No. 1, pp. 151162, doi: 10.1007/s10551-015-2821-z.

Ngai E, Hu Y, Wong Y, Chen Y, Sun X. The Application of Data Mining Techniques in Financial Fraud Detection: A Classification Framework and an Academic Review of Literature. Decision Support Systems 2011; 50: 559-569.

Ndraha, Taliziduhu (2007), Kybernologi Sebuah Scientific Movement, Penerbit Sirao Credentia Tangerang Banten.

Nunnally, J. C., \& Bernstein, I. H. (1994). Psychometric theory (3rd ed.). New York: McGraw-Hill.

Rose-Ackerman, S., \& Truex, R. (2012). Corruption and Policy Reform. SSRN Electronic Journal. doi: $10.2139 /$ ssrn.2007152

Sawsan Saadi Halbouni, Nada Obeid, Abeer Garbou, (2016), Corporate governance and information technology in fraud prevention and detection: Evidence from the UAE, Managerial Auditing Journal, Vol. 31 Issue: 6/7, pp.589-628, https://doi.org/10.1108/MAJ-02-2015-1163

Sharma, Anuj., Panigrahi, Prabin Kumar (2012). A Review of Financial Accounting Fraud Detection based on Data Mining Techniques, International Journal of Computer Applications 39(1)· September 2013

Shim, Dong Chul, Eom, Tae Ho (2008), E-Government and Anti-Corruption: Empirical Analysis of International Data, International Journal of Public Administration Publication details, including instructions for authors and subscription information: http://www.informaworld.com/smpp/title $\sim$ content $=\mathrm{t} 713597261$

Ott, Thomas P., (2010), US law enforcement strategies to combat organized crime threats to financial institutions, Journal of Financial Crime, Vol. 17 Issue: 4, pp.375-386, https://doi.org/10.1108/13590791011082742

Tseng,Lu-Ming., Kang,Yue-Min., Chung, Chi-Erh. (2014),"Understanding the roles of loss-premium comparisons and insurance coverage in customer acceptance of insurance claim frauds", Journal of Financial Crime, Vol. 21 Iss 3 pp. $321-335$

Tuanakotta, Theodorus M. (2007). Akuntansi Forensik dan Audit Investigatif Jakarta: Lembaga Penerbit Fakultas Ekonomi Universitas Indonesia

Undang-Undang Republik Indonesia Nomor 31 Tahun 1999 tentang Pemberantasan Tindak Pidana Korupsi

Pellegrini, L., \& Gerlagh, R. (2004). Corruption's Effect on Growth and its Transmission Channels. Kyklos, 57(3), 429-456. doi:10.1111/j.0023-5962.2004.00261.x

Prabowo, H.P, Cooper, Kathie., Sriyana, Jaka., Syamsudin, Muhammad. (2017) "De-normalizing corruption in the Indonesian public sector through behavioral re-engineering", Journal of Financial Crime, Vol. 24 Issue: 4, pp.552-573, https://doi.org/10.1108/JFC-10-2015-0057

Simpson, S. S. (2013). White-Collar Crime: A Review of Recent Developments and Promising Directions for Future Research. Annual Review of Sociology, 39(1), 309-331. doi:10.1146/annurev-soc-071811-145546

Quah, Jon S. T. , (2015) "Singapore's Corrupt Practices Investigation Bureau: Four suggestions for enhancing its effectiveness", Asian Education and Development Studies, Vol. 4 Issue: 1, pp.76-100, https://doi.org/10.1108/AEDS-10-2014-0049 
Wertz, J., Zavos, H., Matthews, T., Gray, R., Best-Lane, J., Pariante, C. M., Moffitt, T.E. \& Arseneault, L. (2016). Etiology of pervasive versus situational antisocial behaviors: A multi-informant longitudinal cohort study. Child Development, 87(1), 312-325.

Xinli, H. (2015). Effectiveness of information technology in reducing corruption in China. The Electronic Library, 33(1), 52-64. doi:10.1108/el-11-2012-0148

Yusuf, T. Olalekan., \& Babalola, A. Rasheed. (2009). Control of insurance fraud in Nigeria: an exploratory study (case study). Journal of Financial Crime, 16(4), 418-435. doi:10.1108/13590790910993744

Zhou, Wei., Kapoor, Gaurav.(2011), Detecting evolutionary financial statement fraud; Decision Support Systems doi:10.1016/j.dss.2010.08.007

\section{Media :}

http://nasional.tempo.co.id/ diakses 31 Januari 2019

http://www.detiknews.com diakses 31 Januari 2019

https://kabar24.bisnis.com/read/20180608/15/804385/tanri-abeng-indonesia-krisis-pemimpin-bukan-ekonomi 